\title{
Development of Value-Based Leadership: Model in Quality Culture Improvement on Primary Schools
}

\author{
Asep Suryana \\ Departemen Administrasi Pendidikan \\ Universitas Pendidikan Indonesia \\ Bandung, Indonesia \\ doef@upi.edu
}

\author{
Minnah El Widdah \\ Program Studi PGMI \\ IAIN STS Jambi \\ Jambi, Indonesia
}

\begin{abstract}
Leader's personal values and commitment related to school quality culture. Principal leadership with universal-values in primary schools can improving culture quality in primary Schools. This study is aimed to analyze strengthened-universal values in primary schools, culture quality improvement, and the development of value-based leadership in terms of culture quality improvement. Qualitative method was employed to find out the descriptive of the development of value-based leadership model. The findings of this study are the foundation of value-based leadership is important for creating school's culture and climate; strengthened-universal values must be woven together in curricula and extracurricular activities demonstrated in forms of discipline, esteem, obedient, responsibility, honesty, cooperation, and commitment. Whatever, quality culture development, along with school's culture, climate, programs, and external environment, can be demonstrated by thoughts and attitudes that are verified either by tangible or intangible things continuously.However, development Model in Quality Culture Improvement on Primary Schools starting with the activities, curricular and extracurricular, based on values, either cultural or social values. Then, schools must be able to create climate that is based on values so that it will create a relaxed climate as well.
\end{abstract}

Keywords-personal value-based leadership, school's quality culture, Principals commitment

\section{INTRODUCTION}

There are some key factors for transforming schools to be kinds of organizations that form values. Firstly, the referred values must be based on religious and life values. Secondly, the developing values must be universal values. Thirdly, the understandable and personal values of students must be the students' guidelines for their life in society. Fourthly, the transformed values will be applied in science development. Then, a good value-transformation process is based on good understanding of those values. Lastly, head of school will be the first person who applies those values. As an important figure, head of school must be able to play his (her) role as an educator to transform school direction and achievements, achieve the goals, choose the appropriate strategy and bring innovation in administrating the school without disturbing school's dynamic. As a manager, (s)he must be able to manage every managerial activity through creative and attractive understanding. As a supervisor, (s)he must be able to answer the problems of learning activities through a good and right example. The personal values profile, the predominant leadership styles, the leadership effectiveness, and the relationship between personal values balance and leadership effectiveness of a group.[1] Integrating theory and research on values, diversity, situational strength, and team leadership, we proposed that team leadership moderates the effects of values diversity on team conflict.[2]

The leadership of head of school must be able to bring school members to work culture that is full of values and can be used as the cornerstones for them to overcome the external obstacles and adjust them into the organization that they understand what the values are and how to elaborate them with their individual values.. Several expected characters of school culture can be demonstrated by initiatives initiated by every school member, tolerance among school members and groups, clear directions for achieving the goals, commitment and integration of every part of school, supports for school management, supervision, organization identity, appraisal system, and well-established communication. The role of team member goal orientation in team functioning, research has neglected the effects of diversity in goal orientation.[3]

Leadership is a process of influencing and working together to achieve any kind organization's goals, including schools. A school is a non-free-value organization. Educating process in schools is to produce educated people where values are attached to it. Schools have work culture that becomes guidelines for the members to overcome external problems and adjust with organization so that the members of organization can understand what kind of values the organization have and are able to elaborate them with individual values. Organization Culture and Leadership culture is: A pattern of shared basic assumptions that was learned by a group as it solved its problems of external adaptation and internal integration, that has worked well enough to be considered valid and, therefore, to be taught to new members as the correct way to perceive, think, and feel in relation to those problems.[4]

\section{RESEARCH METHODOLOGY}

The methodology was employed in this study is qualitative that focuses on the descriptive-developed model of value-based leadership by looking at the outcomes contributed for developing quality culture in primary schools that later are stratified into high-quality schools, average schools, lowquality schools. Data sources needed for developing quality 
culture in primary schools through the development of valuebased leadership are classified into two categories. Firstly, primer data sources for data about educational management in primary schools and how to run it. Secondly, seconder data sources about implementation of how a principal does his functions and job desks, school condition according to its members' perspective, community's involvement in school, and artifacts that shows school quality culture. Data collection techniques used in this study are observation, survey, and interview. Data analysis and discussion are done through focused-group discussion for finding out imperative implications as finding alternatives and recommendations of this study.

\section{RESULTS}

Principal has a very important role to increase quality of education. The ability of principal in leading will give significant contributions in building work culture in schools. Also, as a leader, principal, together with other school members, should be able to build values and norms in school. Value is an important thing in an organization for achieving its goals. Communication, Network Development, and LeaderTeam Exchange were tested with regard to how individual differences of leaders (intelligence, experience, and personality), the team's network (size, interconnectedness, and embeddedness), the given problem domain (strategic change or innovation), and problem focus (task or relationship focused) influenced the use of each collective leadership dimension.[5]

The Value-Based Leadership indicator finding in this research, look at the table I.

TABLE I. VALUE-BASED LEADERSHIPINDICATOR

\begin{tabular}{|c|c|c|}
\hline No & Indicator & Details \\
\hline 1. & $\begin{array}{l}\text { The personal } \\
\text { values } \\
\text { owned by } \\
\text { the } \\
\text { principals }\end{array}$ & $\begin{array}{l}\text { The personal values should be owned by the } \\
\text { principals are honesty in words and deeds, self- } \\
\text { acceptance, self-control, self-adjustment, self-fair } \\
\text { treatment, selfachievement, self-forwarding, } \\
\text { building ability, articulating hopes, } \\
\text { communication, physical symbols, self-evaluation, } \\
\text { obedience, harmony, and never give up. }\end{array}$ \\
\hline 2. & $\begin{array}{l}\text { The } \\
\text { commitment }\end{array}$ & $\begin{array}{l}\text { This implies the principals developed organization } \\
\text { values well, as well being a part of group. In } \\
\text { developing commitment in their schools, they put } \\
\text { cooperation that gets along with togetherness, } \\
\text { discipline, and examples. }\end{array}$ \\
\hline 3. & Work ethics & $\begin{array}{l}\text { The work ethics, here, involves never postponing } \\
\text { work, maintain teamwork, initiative, solution } \\
\text { provider, innovator, flexible in relationship. Also, } \\
\text { the work ethic is reflected by teachers' attitudes as } \\
\text { good teachers that maintain a good relationship } \\
\text { with students }\end{array}$ \\
\hline 4. & $\begin{array}{l}\text { Personnel's } \\
\text { work } \\
\text { discipline }\end{array}$ & $\begin{array}{l}\text { The personnel has used work procedure, followed } \\
\text { it, and has good time management and allocation. }\end{array}$ \\
\hline 5. & $\begin{array}{l}\text { work quality } \\
\text { of personnel }\end{array}$ & $\begin{array}{l}\text { The personnel has done the procedure, had } \\
\text { procedure clarity, had a linearity with the plan, } \\
\text { work neatness, satisfying (according to goals), } \\
\text { smoothen the next work. }\end{array}$ \\
\hline 6. & $\begin{array}{l}\text { The } \\
\text { relationship } \\
\text { patterns of } \\
\text { personnel }\end{array}$ & $\begin{array}{l}\text { Have had vision and mission, do their job desks, } \\
\text { had work structure, a relationship in work, } \\
\text { responsibility, cooperation, and harmonization. All } \\
\text { of those aspects have been done well. Also, it was } \\
\text { found that the relationship between teachers and } \\
\text { students must be close yet assertive. }\end{array}$ \\
\hline
\end{tabular}

Personal values will affect how someone works in an organization. Work ethics will portray someone's enthusiasm towards his work and this shows basic values perceived by that person. Values will distinguish people. Organizational values will direct the members of organization to have the same perspective in work. Personal values forming work ethics are derived from organizational culture. The same patterns from people whom working is hope. Those patterns must be started from personal values that refer to organizational values. Leader's personal values that are trapped in self-values will not for work ethics as organizational artifacts. Employees who strongly identify with the organization are more likely to be viewed by others as a source of leadership.[6]

Principal's leadership is supposed to give positive contribution to members' behavior and attitude patterns in doing their job desks. Based on developed basic values, the leader will form values in work culture as a foundation to obtain a system in an effective process and produce results that are felt, understood, and hoped by all people. To lead is to inspire others to realize their best potential. It then integrates them with theories of holistic development that offer insight into the most effective ways to access the best potential of enterprise members.[7]

The principal influences people to achieve the goals using their basic values so one point of trust appears regarding developed organizational values that is demonstrated in vision and mission integrated with personal goals when that person enters the organization. Principal's loyalty and personal values will give a direction to high quality work formation where attitudes, behaviors, and relationship patterns are built well. The last point of schools is achieved goals. Its effectiveness is strongly influenced by attitudes, discipline, relationship and commitment of every school's member. Besides loyalty, a leader needs commitment, communication ability, and organizational culture understanding. Better changes are started when a leader has a high commitment towards organization. To bring all elements for achieving the goals, flexible, clear, people-centered communication is needed as well. Commitment is integrated in organizational leadership. The relation between individual perceptions of supervisors' transformational leadership and job satisfaction was mediated by trust in the supervisor as well as trust in the team. Yet, trust in the team did not mediate the relationship between team perceptions of supervisors' transformational leadership and team performance.[8]The focal point is that power and effective leadership are not interchangeable and should not be treated as such.[9]

Work culture in schools is an important element for achieving school's goals. Also, it becomes the standard whether the organization is able to achieve the goals successfully. Principal is supposed to know and have ability to build school's culture. Work culture is built from organizational values that are built by the principal. Work culture is developed through the developed values in schools. School norms are the standards for every member of organization to adjust his attitudes with his membership. Work culture is characterized by the variety of school's members that 
becomes school values. When every value belongs to an individual is accommodated with school values, comfort will be created for school's members to work on his job desks. It is an important thing to share values as fundamental foundation to build a good relationship among people in a school. Valuebased leadership builds individual values and ensures value shares among organizational members. Power is a tool while effective leadership is a skill. Leadership development more seriously, however, in order to raise the bar the sector needs to be seen to invest more in development.[10]

Culture and leadership is like a coin in terms of when leader forms culture and organization at the same time. Existing organizational values must be translated clearly by the leader so that they can be the cornerstones for its members. The leader must understand the function of every element in organizational culture and be able to manage changes to be in line with dynamic external condition. Value-based leadership consists of two elements, which are commitment and personal values. A primary school is the first school context for students, here, students' characters must be formed well. Early character formation will be the implanted foundation for the students when they become adults. The responsibility of implanting values and characters belong to both parents and schools. Less is known about what specific behaviors leaders enact to manage followers' negative emotions. And, importantly, what is the influence of these behaviors on important job-related outcomes such as relationship quality, contextual performance and satisfaction?. [11]Those two things are important for value-based leadership because they will be the foundation of school's work culture formation and quality culture. [12]

The growing school culture portrays basic developed characters in an organization. Those characters become inherent in every person in organization. This can be seen from daily interaction among people in that organization; among teachers; between teachers and students; between teachers and staff; between teachers and school committee; among students; and other informal interactions in school. Values based leadership (VBL) evolved as a product of the time and culture. Values-based leaders can fail in demonstrating that they care about people. Perhaps, the most common are complaints about leaders not listening to people or visibly demonstrating concern for the long-term best interest of the organization. [13]

Valuable characters that appear from such interactions are: 1) initiative and creativity from members; 2) tolerance among people in organization; 3) self-motivation to obtain goals; 4) integration among people in organization; 5) management affectivity and efficiency; 6) supervision affectivity for all members have self-supervision; 7) those values become real expected artifacts; 8) good and comprehensive appraisal system; 9) good communication in various channels, formal or informal, from managerial to operational, even from operational to managerial. A leader needs abilities to develop school culture such as: a) ability to improve school members' skills and commitment; b) ability to make decisions and manage resources; c) ability to innovate; d) ability to provide and give appraisal, develop, save, and preserve the best organizational potencies; e) ability to scan current and future market trends; f) to recruit and knock off executives strategically; g) process quality; h) ability to invent and use knowledge for developing. Value- based leadership is a new approach in leadership that takes in to account both aspects of harmonizing employees and stabilizing common values and attending to major personal differences simultaneously.[14] Our findings reveal important differences between leadership styles in communication and team outcomes (objective task performance and creativity). These results suggest that different dimensions of transformational leadership should be emphasized depending on the outcome sought.[15]

\section{CONCLUSION}

Generally, researcher concluded that value-based leadership is a very important thing to form school's culture and climate. Specifically, universal values reinforcement in primary school administration is manifested in both curricular and extracurricular activities. The values are discipline, respect, obedience, responsibility, honesty, cooperation, and commitment. The development of quality culture in educational service administration in primary schools is demonstrated in forms of attitudes and thoughts in an organization which are done and proven from artifacts in schools that can be seen from intensity and continuity and value-based leadership model development in improving quality culture in primary schools must consider three fundamental components, which are school culture and climate, programs and external environment.

Based on the research findings, research would like to give some suggestions. Firstly, schools are supposed to be able to apply the values in every activity or program that it will create conducive school's culture and climate. Also, schools are supposed to concern other values that come from external environment and family that value synchronization will occur. Thirdly, principal's value-based leadership must be strengthened and demonstrated in school programs so that those values will be implanted in students' life radically. Schools are places where activities, curricular and extracurricular, occur, thus, schools must be able to develop extracurricular activities that are based on values, either cultural or social values. Then, schools must be able to create climate that is based on values so that it will create a relaxed climate as well. School programs are work programs that are derived from all school members' aspiration, including parents and students. Thus, they must be based on values. Whatever, a school is an opened organization so that in its development and administration must demonstrate values, either local culture or religious values that must underlie universal values that are developed in a school.

\section{REFERENCES}

[1] Bruni, Léo F.C and Eduardo G.E. Lay. (2011). Personal values and leadership effectiveness. Journal of Business Research Volume 61, Issue 6, June 2008, Pages 678-683. Strategic Management in Latin America. Published by Elsevier Ltd.

[2] Katherine J. Klein, Andrew P. Knight, Jonathan C. Ziegert, Beng Chong Lim, Jessica L. Saltz. (2011). When team members' values differ: The moderating role of team leadership. Organizational Behavior and Human 
Decision Processes Volume 114, Issue 1, January 2011, Pages 25-36. Published by Elsevier Ltd.

[3] Pieterse, Anne Nederveen, Daan van Knippenberg, and Wendy P. van Ginkel. (2011). Diversity in goal orientation, team reflexivity, and team performance. Organizational Behavior and Human Decision Processes Volume 114, Issue 2, March 2011, Pages 153-164. Published by Elsevier Ltd.

[4] Schein, H. Edgar, (2004). Organization Culture and Leadership. JosseyBass: San Fransisco.

[5] L. Friedrich, Tamara. Jennifer A. Griffith. Michael D. Mumford. (2016). Collective leadership behaviors: Evaluating the leader, team network, and problem situation characteristics that influence their use. The Leadership Quarterly. Volume 27, Issue 2, April 2016, Pages 312-333. Special Issue: Collective and Network Approaches to Leadership. Elsevier Inc.

[6] Donna Chrobot-Mason. Alexandra Gerbasi. Kristin L. Cullen-Lester. (2016). Predicting leadership relationships: The importance of collective identity. The Leadership Quarterly. Volume 27, Issue 2, April 2016, Pages 298-311. Special Issue: Collective and Network Approaches to Leadership. Elsevier Inc.

[7] Best, K. Candis. (2011). Holistic Leadership: A Model for LeaderMember Engagement and Development. The Journal of JVBL; Journal Value-Based Leadership. Current Issue: Volume 4, Issue 1 Winter/Spring 2011. Valparaiso University: USA.

[8] Braun, Sussane. Claudia Peus. Silke Weisweiler. Dieter Frey. (2013). Transformational leadership, job satisfaction, and team performance: A multilevel mediation model of trust. The Leadership Quarterly Volume 24, Issue 1, February 2013, Pages 270-283. Elsevier Inc.
[9] Jones, Angela M. and Sheri L. York. (2016). The Fragile Balance of Power and Leadership. The Journal of JVBL; Journal Value-Based Leadership. Current Issue: Volume 9, Issue 2 (2016) Summer/Fall 2016 ISSN: 1948-0733, Valparaiso University: USA.

[10] Kirchner, Astrid. (2006). Value-based Leadership: A Third Sector View", International Journal of Leadership in Public Services, Vol. 2 Iss: 4, pp. 30 - 33. Emerald Group Publishing: USA.

[11] Little,Laura M. Janaki Gooty. Michele Williams. (2016). The role of leader emotion management in leader-member exchange and follower outcomes. The Leadership Quarterly. Volume 27, Issue 1, February 2016, Pages 85-97. Elsevier Inc.

[12] Copeland, Mary Kay. (2014). Values based leadership (VBL) evolved as a biproduct of the time and culture. International Journal of Leadership Studies (IJLS), Vol. 8 Iss. 2, 2014 @ 2014 School Business and Leadership, Regent University ISSN 1554. St. John Fisher College: USA.

[13] Viinamaki, Olli-Pekka. (2009). Intra-organizational challenges of values-based leadership. EJBO Electronic Journal of Business Ethics and Organization Studies, Ejbo_vol14_no2_pages_6-13.pdf, Vol. 14, No. 2. Publisher: Business and Organization Ethics Network: Berlin.

[14] Badri shatalebi. (2011). Value based leadership paradigm. Procedia Social and Behavioral Sciences Volume 15, 2011, Pages 3703-3707 3rd World Conference on Educational Sciences - 2011. Published by Elsevier Ltd.

[15] Boies,Kathleen. John Fiset, Harjinder Gill. (2015). Communication and trust are key: Unlocking the relationship between leadership and team performance and creativity. The Leadership Quarterly. Volume 26, Issue 6, December 2015, Pages 1080-1094. Elsevier Inc. 